\title{
Moral Reflections on Strict Liability in Copyright
}

\author{
Patrick R. Goold*
}

\begin{abstract}
Accidental infringement of copyright is a pervasive and largely ignored problem. In the twenty-first century, it has become increasingly easy to infringe copyright unintentionally. When such accidental infringement occurs, copyright law holds the user strictly liable. Prior literature has questioned whether the strict liability standard is normatively defensible. In particular, prior literature has asked whether the strict liability standard ought to be reformed for economic reasons.

This Article examines the accidental infringement problem from a new perspective. It considers whether it is fair to hold copyright users strictly liable for accidental infringements of copyright. This Article argues that the strict liability standard is not fair because it results in copyright users being held liable for accidents for which they are not morally responsible. Using the moral philosophy literature on responsibility, this Article explores our intuitions surrounding copyright's liability standard in order to better understand why strict liability in this context seems "harsh" and "inequitable." In turn, this provides an argument for reforming copyright's liability rule and adopting a negligence standard. This Article then argues that, within the United States, the proposed reform to copyright's liability rule should be accomplished by modifications to the existing fair use doctrine.
\end{abstract}

* Senior Lecturer, The City Law School, London, UK. This Article benefited from helpful feedback from Thomas Bennett, John C.P Goldberg, Dmitry Karshtedt, Rebecca Tushnet, David Simon, and colleagues at The City Law School. The author would also like to thank countless individuals at workshops and elsewhere who have provided ongoing commentary on the author's research into intellectual property and private law theory.

(C) 2021 Goold. This is an open access article distributed under the terms of the Creative Commons Attribution License, which permits unrestricted use, distribution, and reproduction, provided the original author and source are credited. 
TABLE OF CONTENTS

Introduction

I. Considering Copyright Accident Case Law: Intitial Moral Intuitions ..127 A. Authors Guild, Inc. v. HathiTrust: The Orphan Works

Project 128

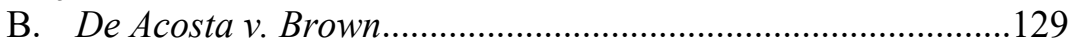

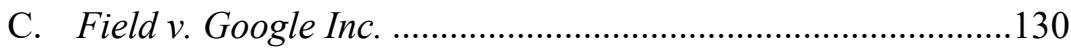

D. Literature Review....................................................................132

II. Moral Responsibility and Copyright Infringment ...............................134

A. Moral Culpability and Blameworthiness ...............................135

B. Causation and Its Role in Determining Moral Responsibility.139

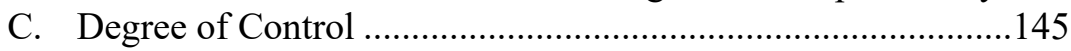

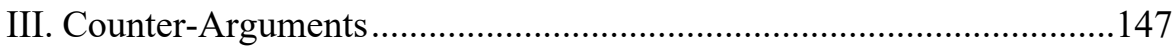

A. Copyright as a Property Right...................................................147

B. Changes To the Remedies Available for Infringement............149

C. Consequentialism and Copyright Infringement .......................150 IV. Reforming Copyright's Strict Liability Standard: Replacing Strict

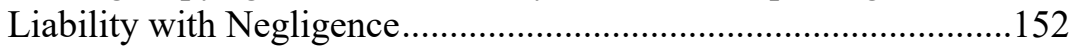

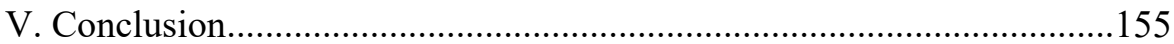

\section{INTRODUCTION}

In May 2011, the University of Michigan undertook a large-scale project designed to facilitate digital access to out-of-print works from their library. ${ }^{1}$ Known as the "Orphan Works Project" ("OWP"), the University's project was intended to increase worldwide access to orphan works - often rare or difficult to find books - and could have saved some of these works from obscurity. An orphan work is defined as "an out-of-print work that is still in copyright, but whose copyright holder cannot be readily identified or located." " At the outset, the University recognized that it would be difficult to determine whether the orphan works were protected by copyright and, if so, who owned the rights. To avoid this problem, the University performed a search for any potential copyright owners and published a list of the suspected ownerless works online, calling for right holders to come forth. ${ }^{3}$ If no one emerged and claimed copyright, the work would be made available online in digital format. Imagine the University's surprise when the Authors Guild (an organization that advocates on behalf of authors in the United States) sued the University for copyright infringement. Mired in a legal quagmire, ${ }^{4}$ the University suspended the OWP

1. Authors Guild, Inc. v. HathiTrust, 755 F.3d 87, 92 (2d Cir. 2014).

2. Id.

3. Id.

4. Id. 
indefinitely, and access to the works remains limited as a result. ${ }^{5}$ However, because the court held that the Authors Guild's claims regarding infringement in connection with the OWP were not ripe for adjudication, the court failed to reach the merits of whether or not the University was liable for copyright infringement. ${ }^{6}$

This story is a familiar one to any intellectual property ("IP") lawyer. Copyright infringement is a strict liability tort: Liability attaches when someone infringes the right, regardless of how carefully the defendant tried to prevent any legal wrongdoing. ${ }^{7}$ The University of Michigan's attempt to avoid copyright infringement was laudable, but largely irrelevant for purposes of liability. No statute says that copyright liability must be imposed in this strict fashion; the rule is entirely judgemade. In the early twentieth century, Judge Learned Hand presided over a string of music copyright cases later cited favorably by the Supreme Court. ${ }^{8}$ The defendants in these cases argued they had not copied the copyright owner's song intentionally, and thus ought to escape liability. Judge Hand, however, had "no difficulty" in finding the defendants liable. ${ }^{9}$ At that time in American history, all copyrights had to be registered with the U.S. Copyright Office. ${ }^{10}$ Accordingly, Judge Hand had little sympathy for the defendants' claims of ignorance. He found that because of the copyright register, everyone was on "notice" of the work's legal status. ${ }^{11}$ Each defendant, in Judge Hand's view, had the "means of knowledge" that the work was copyrighted, and thus took their chances when they published their songs "without any inquiry."12 Since then, Congress has eliminated the requirement that creative works be registered with the Copyright Office as a condition for copyright protection, but the rule that liability is strictly imposed has remained. ${ }^{13}$

5. Because the OWP has not made digital copies of the orphaned works available, anyone wishing to view the works at issue in HathiTrust must find an original print copy. Alternatively, access to limited portions of the work may be available at other locations online as allowed by fair use, for example via snippet view. See generally Authors Guild v. Google, Inc., 804 F.3d 202 (2d Cir. 2015).

6. HathiTrust, 755 F.3d at $104-05$

7. See, e.g., Buck v. Jewell-La Salle Realty Co., 283 U.S. 191, 198 (1931); Shapiro, Bernstein \& Co. v. H.L. Green Co., 316 F.2d 304, 308 (2d Cir. 1963); De Acosta v. Brown, 146 F.2d 408, 411 (2d Cir. 1944).

8. Buck, 283 U.S. at 198 (citing Stern v. Jerome H. Remick \& Co., 175 F. 282 (C.C.S.D.N.Y. 1910); Hein v. Harris, 175 F. 875 (C.C.S.D.N.Y. 1910), aff'd, 183 F. 107 (2d Cir. 1910); Haas v. Leo Feist, Inc., 234 F. 105 (S.D.N.Y. 1916)).

9. Stern, $175 \mathrm{~F}$. at 282.

10. Copyright Act of $1909 \S 5$, repealed by Copyright Act of 1976.

11. Stern, $175 \mathrm{~F}$. at 282 .

12. Id. See also Haas, $234 \mathrm{~F}$. at 107 ("When, as in copyright, the law provides a form of notice, it imposes upon every one at his peril the duty to learn the facts conveyed by the notice. Without some such rule it could not be a tort innocently to copy a copyrighted work, because it could not be said that among the reasonable result of the defendant's acts was comprised an infringement.").

13. See R. Anthony Reese, Innocent Infringement in U.S. Copyright Law: A History, 30 CoLuM. J.L. \& ARTS 133, 175 (2007) ("As the copyright system evolved over the last century, all of the doctrines and features that mitigated the potential negative effects of liability for unknowing infringement were removed from the system. The legal changes ... resulted in copyright's moving away from using constructive notice and knowledge requirements to reduce the risk of innocent infringement, and replaced those mechanisms with adjustments in remedies as the sole recognition of an innocent infringer's lack of culpability."). 
In previous research, Professor Oren Bracha and I conceptualized cases like the Orphan Works Project as "Copyright Accidents."14 The University of Michigan did not intend to infringe copyright; indeed, the library went to great lengths to prevent such infringement from occurring. Nevertheless, had the University actually publicly distributed copies of works which were later found to be copyrighted, the law would hold them, and any other similarly situated users, strictly liable for their accidental infringement of such rights. In our prior work, Bracha and I argued against the strict liability rule. Drawing on Guido Calabresi's famous work, The Costs of Accidents, we argued that holding copyright users strictly liable for accidental infringement is economically inefficient. ${ }^{15}$ Under a strict liability rule, the user has an incentive to take care to avoid such accidents, but the copyright owner does not. ${ }^{16}$ Consequently, while a user like the University of Michigan will likely try to prevent accidents (for example, by publishing a list of works to be digitized online and calling for copyright holders to come forward), right holders often do not proactively prevent accidents with equal diligence. The result is that society must live with a higher rate of copyright accidents than is ideal.

In this Article, I consider the accidents problem from a more common sense perspective. In doing so, I focus less on the consequences of strict liability in copyright, and contemplate instead the moral side of accidental infringement. My question is not whether strict liability fails to properly deter accidents or inhibits creativity (which it does), but more simply, whether strict liability is fair. I make an argument that strict liability is not fair because it results in copyright users being held liable for accidents for which they are not morally responsible. The University of Michigan case illustrates the point well. In this case, the University took all the measures we could reasonably expect of them to avoid the infringement: They performed a diligent search for legal ownership information, they made their plan public, and they asked relevant copyright owners to come forward. If the copyright owners had only taken the relatively straightforward step of responding to that public call for information, the infringement could have been avoided entirely. Yet, if the OWP had publicly launched and was later found to contain copyrighted works, it is the University that, in the eyes of the law, would have been the responsible party and thus subject to liability. This result may seem peculiar, but it is hardly atypical in the world of copyright. Even if we assume that the copyright system as a whole is broadly fair and just, the above example shows that the strict liability standard can, at times, produce counterintuitive results.

Of course, claims about moral responsibility are hardly easy to establish. "Responsibility" is arguably an essentially contested concept. ${ }^{17}$ The goal of this Article is to explore our moral intuitions surrounding strict liability in the hope of

14. Oren Bracha \& Patrick R. Goold, Copyright Accidents, 96 B.U. L. REV. 1025 (2016).

15. Id. (discussing GUIDO CALABRESI, THE COSTS OF ACCIDENTS (1970)).

16. Id.

17. Walter Bryce Gallie, Essentially Contested Concepts, 56 PROC. ARISTOTELIAN SOC'Y 167 (1956). At the very least, there are highly competing understandings of "responsibility." See, e.g., H.L.A. HART, PUNISHMENT AND ReSPONSIBILITY: ESSAYS IN THE PHILOSOPHY OF LAW 211-30 (2d ed. 2008) (providing a five-fold taxonomy of conceptions of responsibility). 
expressing, more clearly than prior literature, why it is that strict liability strikes many as unfair and what, if anything, we could potentially do to remedy that unfairness. I do so in four parts. Part I picks up the story of the OWP case and supplements it with a range of additional cases where strict liability leads to outcomes that are likely to strike many as prima facie unfair. Part II then proceeds to explore our intuitions in these cases. There are many reasons why we may plausibly label someone as "responsible" for an accident. For example, we may say that a defendant is responsible for an accident because they "caused" it, or because the defendant is, in some sense, "to blame" for the accident, or even because the accident was within the defendant's "control." But, as we shall see, these reasons do not provide a strong basis of support for deeming the copyright user responsible in the cases identified in Part I. Part III then turns to several counter-arguments. These include the argument that strict liability is an "essential" feature of property law, and the argument that whatever unfairness exists can be resolved by more lenient remedies rather than changes to the underlying liability structure. Lastly, Part IV considers reform. The proposed reforms include modifications to the fair use doctrine that would facilitate the introduction of a negligence liability rule into copyright, which in turn would lead to a fairer allocation of responsibility in cases of accidental infringement. In exploring our moral intuitions surrounding liability and copyright, this Article provides a perspective that is perhaps unusual and underrepresented in the heavily utilitarian world of IP literature. But as we shall see, it is a valuable perspective when considering the growing problem of accidental infringement.

\section{CONSIDERING COPYRIGHT ACCIDENT CASE LAW: INTITIAL MORAL INTUITIONS}

Accidents are an ever-present feature of modern life. Frequently, we engage in beneficial activities which, as a byproduct, pose a risk of harm to others around us. Sometimes that risk materializes into a reality, and others are injured, even though we did not mean for that to happen. ${ }^{18}$ Copyright is no different in this regard. ${ }^{19}$ Creativity is overwhelmingly positive for society: Creativity is the source of great art and a driver of social change. But creativity (or using creative works) is also risky. In a world filled with intellectual property rights, creating a new novel, song, or work of art, or indeed simply using such products, always risks infringing the copyright of prior authors. There are, of course, measures we can take to minimize that risk. By acting with due care, searching out potential copyrights, and considering whether or not any elements of a prior work we wish to use in a new work are protected by copyright, we can reduce the probability that our actions will infringe any relevant copyrights. But it is unlikely that we can prevent all accidents. Even when we act carefully - as the University of Michigan attempted to do when it published its list of orphan work candidates to allow copyright owners to come

18. STEVEN SHAVELL, ECONOMIC ANALYSIS OF ACCIDENT LAW 1 (1987) (defining "accidents" as "harmful outcomes that neither injurers nor victims wished to occur-although either might have affected the likelihood or severity of the outcomes").

19. Bracha \& Goold, supra note 14 , at 1026. 
forward - it is likely that some infringement of copyright will occur. When such accidents do inevitably occur, current copyright doctrine holds the defendant strictly liable. Yet, as this Part highlights, this leads to counterintuitive results. The cases discussed below hint that something is not quite right in copyright law. This Part ends with a summary of academic literature that expresses the same intuition.

\section{A. Authors Guild, Inc. V. Hathitrust: The Orphan Works Project}

The Introduction has already highlighted how, in Authors Guild, Inc. v. HathiTrust, there is an intuitive sense that, had the court reached the merits of the infringement claim, labeling the University as the party that is responsible for the accident does not seem quite right. But perhaps the law already contains a mechanism to addresses these concerns? We have yet to consider copyright's famous fair use doctrine. ${ }^{20}$ This doctrine exempts from liability otherwise infringing actions that are found to be fair under a four-factor, case-by-case analysis. Tellingly, the doctrine is sometimes referred to as an "equitable rule of reason." 21 Perhaps, therefore, the explicitly equitable focus of the fair use doctrine already serves to redress the apparent unfairness of the strict liability rule. If so, then the University would have had nothing to worry about, because had the court ruled on the infringement claim, it could have successfully asserted the fair use defense and avoided liability. ${ }^{22}$

Yet, it is not clear whether the fair use doctrine would indeed come to the rescue of the University. To be sure, commentators have made a forceful argument that the OWP, and similar uses of orphan works, constitute fair use, especially when undertaken by nonprofit libraries, archives, or educational institutions. ${ }^{23}$ The case for fair use is supported by the broad social benefits to be gained, the very fact the work is an orphan, and the small likelihood of adverse market impact when the work is not being commercially exploited. But the argument is not airtight. Under the first fair use factor, it is open to debate whether the works are transformative. The University planned to reproduce and display protected material verbatim; therefore the use does not transform the content of the expression. Although a growing body of case law recognizes the transformative nature of uses that copy entire works verbatim for innovative purposes such as digital searches and analysis, those cases could likely be distinguished here. ${ }^{24}$ Specifically, one might argue that the use does

20. 17 U.S.C. $\S 107$.

21. See Sony Corp. of Am. v. Universal City Studios, Inc., 464 U.S. 417, 448 n.31 (1984).

22. In a separate portion of the case involving a different full-text search database of digitized books run by HathiTrust, an organization consisting of several universities including the University of Michigan, the court found that the database was fair use. Authors Guild, Inc. v. HathiTrust, 755 F.3d 87, 97-101 (2d Cir. 2014).

23. See, e.g., David R. Hansen, Kathryn Hashimoto, Gwen Hinze, Pamela Samuelson \& Jennifer M. Urban, Solving the Orphan Works Problem for the United States, 37 COLUM. J.L. \& ARTS 1, 23-24 (2013).

24. See, e.g., Perfect 10, Inc. v. Amazon.com, Inc., 508 F.3d 1146, 1168 (9th Cir. 2007) (finding as fair use the display of thumbnail images of copyright owner's photographs); Authors Guild, Inc. v. 
not involve a transformative purpose because the purpose behind the original distribution of the books - to entertain and inform through access to the books' content - and the OWP's purpose are ostensibly the same. Under the second factor, many of the works were fictional and within the core of copyright. Under the third factor, the University was reproducing and planning to display entire works verbatim. And under the fourth factor, one may say that although the works are out of print, the use of the works in the OWP will affect the copyright holders' ability to put the works back on the market in the future or obtain licensing fees from the University. ${ }^{25}$ The point is not that the OWP or similar projects necessarily fall outside of fair use, but rather that the question of fair use is far from settled.

\section{B. DE ACOSTA V. BROWN}

De Acosta v. Brown is one of the most well-known cases establishing the principle of strict liability for copyright infringement. ${ }^{26}$ De Acosta wrote a screenplay based on the life of Clara Barton, the founder of the American Red Cross, in which she included a fictitious romance between Barton and another character. A year later, Beth Brown completed a biography of Barton in which she copied parts of de Acosta's screenplay related to the fictitious romance, including characters, scenes, and lines of text unique to the de Acosta screenplay. ${ }^{27}$ Brown then contracted with Hearst Magazines to publish extracts from the forthcoming book. De Acosta successfully sued both Brown and Hearst for copyright infringement. The court found that Hearst infringed innocently; it had neither knowledge of Brown's copying nor any reason to know of it. Yet, despite their lack of knowledge of the infringement, Hearst was just as liable as Brown under copyright's strict liability rule.

Judge Hand dissented on this point. ${ }^{28}$ While he accepted copyright's strict liability in general, he argued that a different rule should apply when a person unwittingly copies from an intermediary source with no awareness that the source contains copied expression. Particularly, he expressed concern that requiring

Google Inc., 954 F. Supp. 2d 282, 289 (S.D.N.Y. 2013) (finding as fair use the digital reproduction of millions of copyrighted books and the display of "snippets to the public"), aff"d, 804 F.3d 202 (2d Cir. 2015).

25. To be sure, courts have increasingly shown a willingness to find a lack of market harm in cases where the copyright holder has not previously commercially exploited the work in the same manner the defendant did, prior to the defendant's use, making the risk of market substitution unlikely. See, e.g., HathiTrust, 755 F.3d at 99-101 ("The full-text search function does not serve as a substitute for the books that are being searched."); Cambridge Univ. Press v. Patton 769 F.3d 1232, 1277 (11th Cir. 2014) ("[A]bsent evidence to the contrary, if a copyright holder has not made a license available to use a particular work in a particular manner, the inference is that the author or publisher did not think that there would be enough such use to bother making a license available. In such a case, there is little damage to the publisher's market when someone makes use of the work in that way without obtaining a license, and hence the fourth factor should generally weigh in favor of fair use."). But it would certainly be a big step to say that verbatim copies of entire copyrighted works do not act as a substitute for the original work.

26. 146 F.2d 408 (2d Cir. 1944).

27. Id. at $409-10$.

28. Id. at 412 . 
publishers to internalize the owner's harm would be "an appreciable incubus upon the freedom of the press" and a "not negligible depressant upon the dissemination of knowledge."29 He concluded that Hearst should not be liable where they had no reason to believe the underlying work was copied.

The facts of De Acosta are illustrative of a common kind of accidental infringement in which a defendant obtains permission from one copyright holder to reproduce or copy a work that incorporates additional copyrighted works. As in De Acosta, the defendant may not be aware of the copying of the original work at all. Alternatively, the defendant may be aware of the copying of the original work but erroneously believe a third party's representation as to the legal status of the work or the third party's right to authorize the use. Such cases form the classic problem of a legal triangle, ${ }^{30}$ wherein the liability of the party who is directly at fault, having caused the legal accident, is not a substantive part of the legal dispute between the plaintiff and defendant. ${ }^{31}$ The law has to decide on whom the harm will fall as between two innocents. In the copyright version of this triangle, those two innocents are the owner and the defendant who unwittingly copied by reproducing an original copyrighted work contained within the work of a third party. De Acosta is a case of a copyright triangle consisting of a publisher, an author, and a copyright owner. While the author is the party at fault, the publisher and the owner are both innocents.

\section{FIELD V. GoOgLE INC.}

Lastly, an example where the accidental infringer was not held liable for copyright infringement, Field v. Google Inc., may help to further deepen our understanding of the problem. ${ }^{32}$ As part of the indexing process necessary for its search engine, Google produces and stores a cache copy of each indexed website - that is, a copy of the website's HTML code. Google also offers users access to these cached webpages. In Field, the plaintiff, Blake Field, "decided to manufacture a claim for copyright infringement against Google in the hopes of making money from Google's standard practice."33 Field was aware of Google's caching practice and that he could easily opt out of it by placing into his website's code a "no archive" meta-tag. ${ }^{34}$ This meta-tag would be recognized by Google and the no archiving request would have been honored; the meta-tag was widely known in the website indexing industry as signaling a preference not to be cached. Field placed some short literary works on

29. Id. at 413.

30. See Menachem Mautner, “The Eternal Triangles of the Law”: Toward a Theory of Priorities in Conflicts Involving Remote Parties, 90 MICH. L. REV. 95 (1991).

31. See, for example, Nat'l Bank of Com. v. Shaklee Corp., 503 F. Supp. 533 (W.D. Tex. 1980), a copyright, unfair competition, and misappropriation of likeness case in which the estate executor for a famous newspaper columnist sued a corporation who commissioned and distributed an altered edition of a book containing the columnist's writings that inserted references to the corporations products, even though the corporation sought out permission to do so from the book's various publishers and obtained what they believed to be a valid licensing agreement from the publisher for the book printing.

32. 412 F. Supp. 2d 1106 (D. Nev. 2006).

33. Id. at 1113 .

34. Id. 
his website (entitled, for example, "Good Tea") and set the permissions in a standard file called "robots.txt" to signal that he wanted his website to be crawled and indexed by search engines. Once his website was cached, as Field expected, he sued for $\$ 2,550,000$ in statutory damages, even though Google disabled its users' access to the cached copy of his webpage as soon as it learned of his claim. ${ }^{35}$

In Field v. Google, the district court denied Field's claim. ${ }^{36}$ The circumstances surrounding the case hardly made Field a sympathetic plaintiff. And the court found numerous reasons to reject Field's case, including findings of implied license, estoppel, and fair use. ${ }^{37}$ The court found that Field's conscious decision not to attach the appropriate meta-tag could be "reasonably interpreted" as the grant of a nonexclusive license to Google to create cache copies of the protected material. ${ }^{38}$ Thereafter, the court found that Field's claim was estopped because he had "aided the defendant in infringing" his own work. ${ }^{39}$ Field not only knew of Google's conduct but, by failing to add a "no archive" meta-tag and altering the robots.txt file to allow indexing, he acted in such a way that Google reasonably believed its actions were non-infringing, and Google relied to its detriment on Field's conduct. ${ }^{40}$ Lastly, the court made a finding of fair use. ${ }^{41}$

Although the court was clearly willing to dismiss the claim, the court's reasoning for dismissing the claim is telling. Consider the court's finding of fair use. The court relied on a finding that Google's use of the work was "highly transformative." ${ }^{22}$ But, as with the OWP case, this finding is hardly beyond debate. Field's underlying creative works were not altered or changed in any way. The transformation was in Google's "use" of the work, rather than the content of the work itself. Cache copies allow internet users to access webpages (including, in this instance, the copyrighted works) when they are otherwise unavailable..$^{43}$ Accordingly, the district court found that Google's use (facilitating access) was different than the original purpose of the work (serving an aesthetic function). While this has become an accepted interpretation of the transformative use concept,${ }^{44}$ it is hardly without its detractors. For example, Jane Ginsburg has previously argued that certain uses held by courts to be transformative that involve the distribution of a work in its entirety for a socially beneficial purpose ought not be considered fair use, but should instead be considered a "permitted-but-paid" use, subject to a compulsory licensing regime. ${ }^{45}$

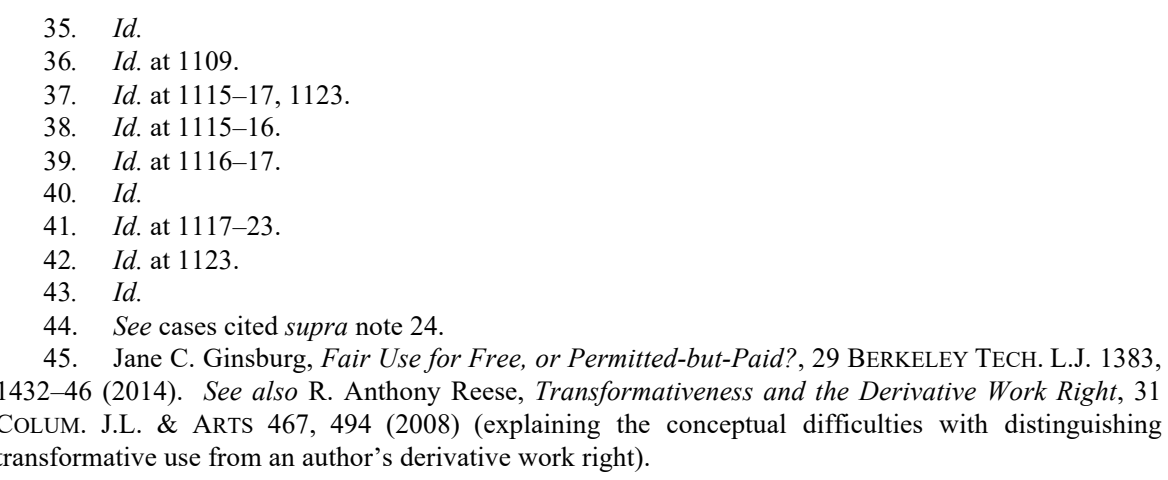


I am not making the argument that the court's analysis was wrong or defective; there are many arguments that support the court's conclusion as well. What I do think, however, is that there was something more significant going on in this case. Given how the court framed its analysis, I would argue that the case can be read as the court recognizing that Field, rather than Google, was the party who was truly responsible for the infringement, and that this motivated the judicial findings. In this regard, certain features of the analysis are telling. In part, the court makes a point of emphasizing that Google gave all website operators an easy way to opt out of their caching project: simply attaching the appropriate meta-tag to their website. ${ }^{46}$ Like the copyright owners of the orphan works in the OWP case, if the copyright owner in this case had only used this opt-out option, the infringement could have been completely avoided. Furthermore, the court added an additional factor to the traditional four-factor fair use analysis: a fifth factor considering the user's good faith. ${ }^{47}$ According to the court, the essence of Google's good faith was the making available to copyright owners an easy and accessible means for opting out, and honoring the owners' wishes once they were signaled through this means. ${ }^{48}$ The court's reasoning can be read as placing significant weight on the fact that Google employed a cost-effective precaution to prevent what was clearly a copyright accident, and the court believed that these actions by Google cut heavily in favor of fair use. Finally, in ruling in favor of Google's defense of estoppel, the court appealed to equity - the body of law designed to address unfairness in our common law rules - to resolve this case. This is another piece of evidence that suggests the court was motivated by a sense that there was something unfair in holding Google liable in Field, and may even suggest that the court recognized an unfairness in the underlying liability architecture of copyright law.

\section{Literature Review}

These highlighted cases leave us with the sense that something is not quite right in copyright law. Of course, in many other cases of infringement, these problems are avoided: In many run-of-the-mill copyright cases, a user will have behaved with some element of fault (for example, by intentionally copying a work in circumstances where they know they ought not to), and thus, even though they are held strictly liable, that strict liability does not seem seriously problematic. But in cases of true innocent infringement, strict liability does invite questions. This sense of moral unease can be found in the existing literature on copyright's liability regime. Starting in the mid-twentieth century, copyright scholars started to question copyright's liability rule.

Early alarm bells rang in an unsigned comment in the Fordham Law Review, Innocent Participants in Copyright Infringement. ${ }^{49}$ The comment noted that "scant

46. Field, 412 F. Supp. 2d at 1122-23.

47. $I d$.

48. $I d$.

49. Comment, Innocent Participants in Copyright Infringement, 8 FORDHAM L. REV. 400 (1939). 
attention" had been paid to the issue of innocent infringers. ${ }^{50}$ Like Judge Learned Hand a decade earlier, the author found that the strict liability standard generally could be defended because of copyright's clear notice requirements. In order to prevent the statute from becoming "harsh beyond measure," the author wrote, "protection to the public is afforded by the strict requirement that notice of copyright ... be affixed to each copy of the work published or offered for sale in the United States" (for example, by attaching copyright information and the famous (C) symbol to the first page of a book). ${ }^{51}$ But, in a prescient move, the comment raised concerns about those who unwittingly copied a work from an intermediary source. ${ }^{52}$ The author highlighted that new technologies, particularly radio and film, often involved multiple individuals working closely to produce the final product. As technologies become more complex, this could lead to a common problem where one individual copies a work, and then another individual later on in the production chain produces copies of the copy, or distributes the copy further, and thus infringes the underlying copyright without any knowledge of (or reasonable means of discovering) the original infringement. Indeed, this was the situation that later transpired in De Acosta v. Brown. ${ }^{53}$ But, despite the author's conclusion that strict liability was "harsh," that normative claim was not unpacked in any significant way in the comment.

The next major installment in the academic history of strict liability came in 1970. Kent Sinclair, Jr., a student at Berkeley, wrote a prize-winning comment arguing that, due to the "inequity," the "harshness," and the "unfairness" of strict liability, courts had developed a rather arbitrary set of rules for limiting damages in inadvertent infringement cases. ${ }^{54}$ But, much like the earlier comment, there was no philosophical reflection on why the strict liability standard results in "inequity." Of course, the article does consider, and rebut, a range of reasons one might defend the strict liability rule. ${ }^{55}$ But this reflection is based primarily on policy rather than on principle. Sinclair considers, for example, the argument that "innocence is easy for the defendant to allege and difficult for the plaintiff to disprove," but dismisses it on the ground that criminal law seems to "function satisfactorily" on the basis of presumed innocence and that the problem could be solved by placing the burden of proving innocence on the defendant. ${ }^{56}$ Sinclair does not, however, provide much clarity on why the liability rule seems "harsh" in the first place.

Since Sinclair's comment, much attention has focused on the strict liability standard, but not much of it from a moralistic point of view. ${ }^{57} \mathrm{R}$. Anthony Reese has

50. Id. at 400 .

51. Id. at 401 .

52. Id. at $405-06$.

53. 146 F.2d 408 (2d Cir. 1944).

54. Kent Sinclair, Jr., Comment, Liability for Copyright Infringement-Handling Innocence in a Strict-Liability Context, 58 CAL. L. REV. 940, 940, 945, 980 (1970).

55. Id. at $949-54$.

56. Id. at $950-51$.

57. An article was published recently that may end up starting the discussion on morality and accidental infringement. See Abraham Bell \& Gideon Parchomovsky, Restructuring Copyright Infringement, 98 TEX. L. REV. 679 (2020). But apart from a few sentences in the introduction (for 
explored the historical origins of the strict liability standard. ${ }^{58}$ In particular, he has described how Anglo-American copyright law traditionally adopted a range of measures that prevented individuals from innocently infringing copyright-in particular, mandatory registration and notice provisions made it easier for the public to discover existing legal rights to creative works and thereby avoid infringement. ${ }^{59}$ Furthermore, in some copyright infringement actions (such as cases involving copying by derivation), courts in the eighteenth and nineteenth centuries often did consider the defendant's mental state before imposing liability. ${ }^{60}$ Moving beyond this historical analysis, two scholars have performed conceptual analyses and questioned whether copyright really is a strict liability tort. ${ }^{61}$ Furthermore, in addition to introducing the "copyright accidents" concept, Bracha and I have performed an economic analysis of such infringements and argued that strict liability sets suboptimal incentives for copyright owners to take care to prevent accidents. ${ }^{62}$ Finally, various articles have questioned the justifications for strict liability in copyright, and considered absolving the defendant of liability when said defendant did not intend the infringement. ${ }^{63}$ These analyses rarely consider the role that negligence traditionally plays in the law's treatment of accidents. More importantly for our purposes, these analyses adopt a "multi-policy" analysis, examining the strict liability standard from a number of perspectives, but do not focus specifically on the moral philosophy of responsibility. We now turn to such an analysis in Part II.

\section{MORAL RESPONSIBILITY AND COPYRIGHT INFRINGMENT}

Under what conditions are we morally responsible for a given outcome? While there is clearly no consensus on this (admittedly bluntly framed) question, there are nevertheless a range of possible answers. It might be that we are responsible if we were "to blame" for the outcome. Instead, moral responsibility might lie if we were the "cause" of the outcome. Finally, it could be the case that we are responsible if the outcome was otherwise within our "control." In this Part, I examine the copyright accident cases identified in Part I in light of these three potential bases of moral responsibility. My tentative claim is that all three of these potential bases are relevant factors to assess when considering moral responsibility for copyright infringement. I argue that the current strict liability regime results in liability for some copyright

example: "Infringers are liable for damages that bear no proportion to the moral culpability of the defendant or, for that matter, to the damages that their behavior actually causes." Id. at 682), the article largely provides an economic, not moral, analysis.

58. Reese, supra note 13.

59. Id. at $144-54$.

60. Id. at $154-75$.

61. Steven Hetcher, The Immorality of Strict Liability in Copyright, 17 MARQ. INTELL. PROP. L. REV. 1, 2 (2013); Patrick R. Goold, Is Copyright Infringement a Strict Liability Tort?, 30 BERKELEY TECH. L.J. 305 (2015).

62. Bracha \& Goold, supra note 14.

63. See, e.g., Dane S. Ciolino \& Erin A. Donelon, Questioning Strict Liability in Copyright, 54 Rutgers L. Rev. 351, 353-54 (2002); Avihay Dorfman \& Assaf Jacob, Copyright as Tort, 12 THEORETICAL INQUiRIES L. 59 (2011); Jacqueline D. Lipton, Cyberspace, Exceptionalism, and Innocent Copyright Infringement, VAND. J. ENT. \& TECH. L. 767, 775-84 (2011). 
users when they have not acted culpably, when they have not caused the accident, and when the accident was outside their control. Even under an expansive view of responsibility, therefore, the strict liability standard does not align with our conceptions of fairness. ${ }^{64}$ Because of these fairness concerns, I ultimately argue that copyright should not impose strict liability on defendants in cases of accidental infringement.

A number of caveats are in order before we begin. First, this Article brackets off considerations of causal determinism. A large philosophical literature addresses determinism, and some are of the opinion that our conduct is always caused by some prior state of the world. ${ }^{65}$ In such circumstances our actions are not truly "free" and thus we cannot fairly be deemed as responsible for any outcomes. Addressing such concerns is outside the scope of this analysis. Rather, this Article proceeds on the assumption that agents have some capacity to exercise free will and may fairly be understood as responsible for outcomes under certain circumstances. Second, this Article also takes as its starting point that intuitions are important. It assumes that the intuitive responses that many would have about the Part I cases deserve reflection and examination (and are not merely expressions of ideology). ${ }^{66}$ Finally, a methodological note is required. The following pages consider the contested grounds of moral responsibility. In cases of conflict, I have chosen to side with the broadest reasonable theory of moral responsibility. The aim is to show that even under a broad and expansive understanding of moral responsibility, there is significant moral disquiet surrounding copyright law's strict liability rule.

\section{A. Moral Culpability and Blameworthiness}

One of the most common claims in the philosophical literature on moral philosophy is that moral responsibility requires that the person's conduct was, in

64. The analysis I provide herein is based on the concept of responsibility. Accordingly, this Article does not engage extensively with theoretical ideas and arguments found in the broader literature on strict liability and fault liability that are not necessarily relevant to the issue of responsibility. In particular, this Article does not consider in detail the issues of "reciprocity" and risk taking. For example, George Fletcher has argued that one interpretation of tort law is as a regime for imposing liability when individuals impose "nonreciprocal" risks on each other. See generally George P. Fletcher, Fairness and Utility in Tort Theory, 85 HARV. L. REV. 537 (1972). Fletcher uses this paradigm to explain why in some instances tort law relies on strict liability and at other times relies on negligence liability. As this Part analyzes the issue of whether liability conforms to our intuitions of responsibility, rather than reciprocity, Fletcher's argument is not considered in depth. Likewise, this Part's focus on responsibility means that this Part does not consider in significant detail arguments that the ideal of corrective justice requires either strict liability or negligence liability. See, e.g., ERNEST WEINRIB, THE IDEA OF PRIVATE LAW 145-203 (2d ed. 2012) (arguing that strict liability is incompatible with the juristic concept of corrective justice that is immanent within tort law).

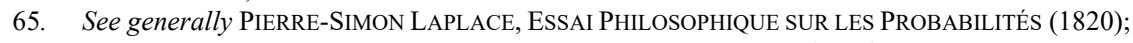
KARL PopPer, THE OPEN UNIVERSE: AN ARGUMENT FOR INDETERMinism (1982).

66. See John Rawls, Outline of a Decision Procedure for Ethics, 60 PHIL. REV. 177, 183 (1951) ("An intuitive judgment may be consequent to a thorough inquiry into the facts of the case, and it may follow a series of reflections on the possible effects of different decisions, and even the application of a common sense rule, e.g., promises ought to be kept. What is required is that the judgment not be determined by a systematic and conscious use of ethical principles."). 
some way, "culpable" or "blameworthy." Philosophers who take this view argue that imposing liability on "innocent" individuals lacks moral foundation. ${ }^{67}$ There is, however, less consensus regarding what counts as blameworthy behavior. Some theorists maintain that an agent only acts culpably if she "intended" to bring about the outcome. Illustrative of this position is R. Jay Wallace's conclusion that responsibility requires a deliberate "choice" to bring about the wrongful outcome. ${ }^{68}$ On the other hand, some adopt a more expansive understanding of culpability. They claim that a defendant may be to blame for outcomes flowing from a failure to comply with some "standard of conduct." 69 For example, Peter Cane argues that "carelessness" or "negligence" may be sufficient to ground moral responsibility. ${ }^{70}$ Some conduct (for example, driving) by itself attracts no moral blame, but such conduct will become blameworthy if the actor fails to perform the activity at a certain standard (for example, sufficient carefulness). For our purposes, we need not enter the substance of this debate. Consistent with the commitment to adopting an expansive view of responsibility, we shall assume for the time being that carelessness is a form of moral wrongfulness.

Under the strict liability standard, copyright law holds liable defendants who have not behaved in a blameworthy fashion. Copyright users are liable for infringements they did not intend and, as in the OWP case, where they did not behave carelessly. This is true even though damages are, in some cases, reduced on the grounds that infringement was not "willful.", " In such cases, courts continue to hold the defendant responsible for the infringement, but decide that a lower level of damages is sufficient to correct the wrongful outcome. The general statement that copyright liability does not require culpability is also true despite the fact that courts occasionally, as in Field v. Google, do show sensitivity to the presence of reasonable care. ${ }^{72}$ In cases where the defendant acts "innocently," courts will sometimes take this into account in the fair use analysis. But innocence on its own is never dispositive.

Arguably, copyright infringement necessarily involves some level of culpability. This argument may be called the "wrongful copying" argument, and it goes as follows: A copyright owner has a moral right to prevent copying of her work and, ergo, any defendant who copies that work without explicit authorization commits a moral "wrong"; the defendant is accordingly "to blame" or "culpable" on the grounds that she has done something inherently "wrongful." " The same argument can be put

67. See, e.g., EdgAR BodenHeIMER, PHILOSOPHY OF RESPONSIBILITY 9-10 (1980); HART, supra note 17 , at $225-26$.

68. R. Jay Wallace, ReSPONSIBILITY AND THE Moral Sentiments 51-75 (1994). See also J. L. MACKIE, ETHICS: INVENTING RIGHT AND WRONG 208-15 (1977).

69. See, e.g., PETER CANE, ReSPONSIBILITY IN LAW AND MORALITY 78-81 (2002).

70. Id. at $65-112$.

71. 17 U.S.C. $\$ 504$.

72. See Field v. Google Inc., 412 F. Supp. 2d 1106, 1122-23 (D. Nev. 2006).

73. To be sure, no one has made this argument exactly, although some have come close. For example, I have previously argued that in order to infringe copyright there must be legal wrongdoing, and thus, on some accounts, liability for copyright infringement may not be truly "strict." Goold, supra note 
in a slightly different way. One may say that morality requires us all to live up to a certain standard; we are directed by morality to "not infringe someone's copyright," and we must try to achieve that standard. A defendant who fails to achieve this standard of conduct behaves culpably by failing to achieve that standard of conduct - much like they would in a negligence case. If such argument is accepted, then moral responsibility can fairly be grounded in the copyright user's wrongful conduct.

I reject the "wrongful copying" argument on the grounds that it confuses two distinct concepts: wrongfulness and culpability. To say that conduct was "wrongful" is to say something about the outcome of the defendant's conduct. Conduct which is wrongful is in breach of someone else's rights. Of course, wrongfulness is not synonymous with harm or loss. One may harm another without doing wrong to that person (for example, there is no wrongdoing in causing someone else a purely economic loss). Conduct only becomes wrongful when one injures the legitimate rights of others. Culpability, however, assumes that the outcome was wrongful, and questions the process through which the wrongful outcome was brought about: Was the defendant "to blame" for bringing about the wrongful outcome? If we consider doctrinal tort law, nearly all (if not all) torts involve wrongfulness, ${ }^{74}$ but not all torts require culpability. ${ }^{75}$ Trespass on land, for example, requires a wrong (a breach of someone else's rights), but there are circumstances in which the defendant has done so without culpability, and trespass law does not typically require courts to assess a defendant's culpability before a defendant will be found liable for trespass. The same is true in copyright law. Another way of framing this point, favored by Peter Cane, is to make a distinction between "conduct" and "standard of conduct."76 In some cases, trespassing on another's land or infringing another's copyright may be morally wrongful conduct, but that tells us nothing about whether the defendant conducted herself in accordance with a qualitative standard, such as how carefully the defendant conducted herself. ${ }^{77}$

Moreover, current copyright liability holds copyright users liable not only when they have behaved innocently, but when other parties have behaved in a more clearly blameworthy fashion. The OWP case and Field, for instance, demonstrate how

61. See also Shyamkrishna Balganesh, The Obligatory Structure of Copyright Law: Unbundling the Wrong of Copying, 125 HARV. L. REV. 1664 (2012) (discussing copyright infringement as a legal wrong). This flows from a view in tort law that some "strict liability wrongs," such as trespass to land, still involve wrongdoing. See John C. P. GoldBerg \& Benjamin C. Zipursky, ReCOGNIZING WrongS 189-98 (2020). I would argue that it is a short step from these arguments to the argument that the copyright user has behaved in a morally wrongful fashion.

74. GOLDBERG \& ZIPURSKY, supra note 73, at 189 ("Tort law hinges liability on wrongful injury.").

75. Indeed, one may go further and argue that criminal law also requires wrongfulness but not necessarily culpability, although more frequently in criminal law both are required.

76. CANE, supra note 69 , at 82-83.

77. I have in this Section made a distinction between wrongfulness and culpability. But this argument leads to a further question: Can wrongfulness in the absence of culpability be sufficient to ground moral responsibility? I consider this question in the next Section on causation. I interpret this question as: If someone causes a wrongful outcome, can they be considered responsible on this ground alone? If so, this does, to an extent, equate "wrongfulness," "wrongdoing," and "causing a wrongful outcome." 
copyright owners are frequently culpable - at least in part - in bringing about the infringement. Field intentionally left out the relevant meta-tags which would have prevented the injury. Similarly, if we assume that some of the copyright owners in the OWP case learned of the call for information but did not take the reasonable measure of responding to the University's call for information, those copyright owners acted in an arguably careless manner. I would argue that the copyright user's failure to take reasonable care measures is a form of moral culpability, in which case, a copyright owner's failure to do the same carries equal blame. Furthermore, the Part I cases demonstrate not only that copyright owners may be rightly "to blame" for the accident, but also that in some instances, intermediaries are more blameworthy than either the copyright owner or the copyright user. In De Acosta, for example, Beth Brown clearly copied Barton's work, thus infringing her copyright. $^{78}$

Some (particularly proponents of strong copyright protections) may be aghast at my suggestion that the copyright owners in the OWP case acted carelessly and thus would be appropriately subject to some level of moral blame for the accident, had the University gone through with the project. As these proponents argue, surely it is the moral duty of the copyright user to secure consent from the owner ex ante, rather than for copyright owners to hawkishly monitor uses of their works. ${ }^{79}$ To give an analogy, if someone at the University of Michigan posts online that they intend to come to my house to raid my refrigerator in two weeks, and that my silence would be interpreted as consent, would it be "careless" of me not to respond? The problem seems particularly acute when one considers that I may have no connection to the hungry University employee and no reason to actively search the internet for such posts.

I disagree that copyright owners are under no moral duty to prevent accidental infringement. The whole premise of contributory negligence is that, in some circumstances, we are to blame for our own misfortune. For example, I have a right to physical integrity: You cannot touch me or physically interfere with me without my consent. Nevertheless, if I drive well above the speed limit, and we collide in a road traffic accident which causes me bodily harm, I will rightly be deemed culpable for not taking sufficient care to prevent my own injury. ${ }^{80}$ Naturally, that does not mean we must adopt self-protective measures no matter how onerous they may be. But we must behave as reasonable people in preventing accidental injury to both others and ourselves. In the case of the hungry University employee above, I clearly am under no duty to respond to the employee's online post. However, not only is that case not an accident case (the employee knows who owns the refrigerator and is

78. De Acosta v. Brown, 146 F.2d 408 (2d Cir. 1944).

79. Although not making a moralistic point per se, Richard Epstein does suggest that the structure of copyright is antithetical to requiring copyright owners to take positive steps to prevent infringement. Richard A. Epstein, What Light if Any Does the Google Print Dispute Shed on Intellectual Property Law?, 7 COLUM. SCI. \& TECH. L. REV. 1, 5-10 (2006). See also generally Oren Bracha, Standing Copyright Law on Its Head? The Googlization of Everything and the Many Faces of Property, 85 TEX. L. REV. 1799 (2007) (arguing that there is nothing in the essence of copyright that prevents the use of opt-outs).

80. See, e.g., Baxter v. Bryan, 122 Ga. App. 817 (Ga. Ct. App. 1970). See also Froom v. Butcher [1976] 1 QB 286 (UK) (involving seatbelt use). 
in a position to bargain ex ante), but asking me to prevent such injury would go beyond the bounds of reasonable care. Compare that to an alternative hypothetical. Imagine the employee finds a refrigerator full of food somewhere. The refrigerator has been left plugged in, and the food is all edible, but there is no ownership information attached to the machine or its contents. Although the employee may surmise that the refrigerator was, at some time, owned, it is not clear whether it is still owned (or alternatively abandoned), who owns it (if owned), and what that owner's preferences are with relation to the food. Being a good moral agent, the employee searches to find out who, if anyone, owns the food, but finds no answer. He then posts online that he will redistribute the food to needy people in two weeks, unless the owner comes forward, and makes sure that post is available in places that a reasonably attentive owner is likely to find it. If two weeks go by, and I, the owner, have not responded, then, in my mind, I have lost the right to complain about his actions. I have not taken sufficient care to prevent my own injury and am accordingly contributorily negligent. Likewise, the copyright owners in the OWP case have, in my mind, not lived up to the standard of reasonable care that we expect of them.

I would argue that the fact that copyright holds users liable in cases where they have behaved innocently, while other parties have behaved culpably, may be at the root of our concerns about moral responsibility in copyright. However, this observation alone does not support the claim that copyright law imposes liability on users who are not morally responsible for the infringement. Although it is common for philosophers to argue that responsibility requires culpability, this is a contested claim. Others argue that we can be morally responsible for outcomes even when we have not behaved culpably. These philosophers tend to defend strict liability in law as consistent with morality. Illustrative of this position is Tony Honoré's famous concept of "outcome responsibility." 81 Honoré argues that, under certain circumstances, we are responsible for outcomes that we brought about with no intentionality or negligence. ${ }^{82}$ We shall return to the substance of this argument later. But for now, it is clear that in our investigation of copyright's liability regime, causing copyright infringement is a potentially sufficient grounds for moral responsibility, and that this may provide a defense of copyright's strict liability regime.

\section{B. Causation and Its Role in Determining Moral ResponsibiLity}

Some ascribe to the view that we are morally responsible for any outcomes that we cause. But, once again, this position is contested. For example, Judith Jarvis Thomson contends that holding an individual responsible for outcomes they did not cause would be an intolerable encroachment upon our freedom of action, and thus

81. Tony Honoré, Responsibility and Luck: The Moral Basis of Strict Liability, 104 L. Q. REV. 530 (1988). 
causation is a necessary requirement of responsibility. ${ }^{83}$ John Fischer and Robert Ennis argue that an individual cannot be held responsible for all of the outcomes she "causes" because whether her conduct "causes" the proscribed outcome is often a matter of luck (a topic we shall return to in Section C). ${ }^{84}$ In legal circles, some have gone further and denied the very possibility that causation, absent a normative notion such as culpability, can generate clear answers to the question of who is responsible for a given outcome. ${ }^{85}$ Translating this debate into the world of copyright accidents further demonstrates that strict liability holds copyright users liable even in the absence of responsibility. The problem is that both copyright owners and copyright users can take measures to prevent copyright accidents. As a result, both could plausibly be considered "the cause" of the accident.

Copyright law holds defendants liable if they were a cause of the copyright accident. In order to infringe copyright, one must act in a way that violates a copyright holder's exclusive rights; for example, by copying a protected work. ${ }^{86}$ Clearly, copying is what lawyers would label a "but-for" cause of the infringement: ${ }^{87}$ But for the University of Michigan's digitizing of the works, the copyright accidents would not have occurred. Thus under the current copyright laws, the defendant will be liable only if she was a cause of the copyright infringement. This much is simple and straightforward.

However, are the actions of other parties not also but-for causes of copyright accidents? The nature of but-for causation means that several acts can simultaneously be but-for causes of a single outcome. For example, though it is not clear from the court's opinion, it's possible that some of the copyright owners in the OWP case failed to respond to the University of Michigan's request for information after learning of the University's request. Had they responded to the request, the University would not have planned to publicly distribute a copy of their work as part of the Orphan Works Project. But for the owner's carelessness, the copyright accident would not occur. Of course, a cynic may argue that the University potentially would have publicly distributed the works regardless of the owner's actions. Indeed, it is true that it is certainly possible that the University would have publicly distributed the works contrary to any express wishes of the copyright owners. However, this seems unlikely. The but-for analysis requires lawyers and philosophers to speculate what would happen in the hypothetical case that the

83. See Judith Jarvis Thomson, Remarks on Causation and Liability, 13 PHIL. \& PUB. AfFS. 101 (1984); see also Richard A. Epstein, A Theory of Strict Liability, 2 J. LEGAL STUD. 151 (1973) (making the same point from a libertarian perspective).

84. John Martin Fischer \& Robert H. Ennis, Causation and Liability, 15 PHIL. \& PUB. AfFs. 33 (1986).

85. See Stephen R. Perry, The Impossibility of General Strict Liability, 1 CAN. J.L. \& JURIS. 147 (1988).

86. See 17 U.S.C. $\S 106$.

87. See, e.g., Barnett v. Chelsea \& Kensington Hosp. Mgmt. [1968] 2 WLR 422 (UK). For our purposes, we need not consider competitors to the famous but-for test, such as the NESS Test (necessary element of sufficient set); it is clear that copying is a factual cause of the outcome without recourse to alternative tests, such as would be necessary in cases of overdeterminism. See H.L.A. Hart \& TONY Honoré, Causation In THe LaW (1985); Richard W. Wright, Causation in Tort Law, 73 Cal. L. Rev. 1735 (1985). 
individual in question behaved differently; and in this case, had the copyright owners used the opt-out option provided to them, it is likely that the University would not have pressed ahead with publicly distributing those claimed works without first obtaining a license from the owner. Even more demonstrative of this point is Field, where, had the copyright owner attached the appropriate meta-tag, Google automatically and without further human intervention would not have cached his works. In these cases, it seems that the copyright owners were just as "causally responsible" as the copyright users.

More generally, what these cases point to is the acknowledgement that copyright owners have significant measures available which, if adopted, can help to avoid copyright accidents. Copyright owners can register their works with the Copyright Office, thus making it easier for users like the University of Michigan to prevent accidental infringement. ${ }^{88}$ Similarly, copyright owners can attach notice to the work, including the (C) symbol, as well as other information about the date of the work's creation and ownership status (thus enabling users to identify when the work falls into the public domain). ${ }^{89}$ Likewise, recordation of copyright assignments and exclusive licenses can be kept and made available to others to help users identify potential right holders. ${ }^{90}$ In cases such as mass digitization projects, users of potentially copyrighted works often give owners an easy, well-publicized, and cheap opportunity for opting out from a particular use of their works. ${ }^{91}$ Owners can take advantage of this opportunity and remove the informational fog shrouding their work and preferences. ${ }^{92}$ Owners also often have available preventive means in cases where works are copied by derivation from a third party who has illegally incorporated the protected work into his own work or misrepresented his rights in regard to the protected work. In such cases, owners have the potential to move expeditiously and effectively against the third party, thereby removing the hazard created by the third party for accidental infringement by others. ${ }^{93}$ I would argue that, in appropriate cases, owners can effectively "spread the word" about such hazards created by illegal or misrepresenting uses of their works. ${ }^{94}$ The variations are many and the list could be extended, but the principle should be clear: By failing to take

88. See Registration Portal, U.S. COPYRIGHT OFF., https://perma.cc/VVY3-42WW (last visited Oct. 28, 2020).

89. And although such notice is not required to obtain protection, the Copyright Act does regulate the form that such notice should take. 17 U.S.C. $\S 401$.

90. This can be accomplished with the Copyright Office. See Recordation of Transfers and Other Documents, U.S. COPYRIGHT OFF., https://perma.cc/4YNB-YNR8 (last visited Oct. 28, 2020).

91. See Bracha, supra note 79, at 1817-35.

92. To the extent that copyright owners wish to enable use of their work, they can signal these preferences through use of open licensing regimes such as Creative Commons licenses. See About the Licenses, CReative Commons, https://perma.cc/H8TE-HZ8B (last visited Mar. 23, 2016).

93. Such as quickly bringing a copyright infringement suit against Brown prior to Hearst's involvement in De Acosta v. Brown, 146 F.2d 408 (2d Cir. 1944).

94. An interesting example of which comes from the world of patent law. When George Selden believed that his patent on automobile engines was being infringed by Henry Ford's Model T car, Selden launched a campaign telling customers that if they were to buy Ford's car, then they would also "buy a lawsuit.” See James J. Flink, The AutomobiLE Age 51-55 (1988). 
reasonable action to prevent the accident, copyright owners are equally but-for causes of copyright accidents. ${ }^{95}$

One might, at this point, attempt to distinguish the position of the copyright user and the copyright owner by appealing to the "acts versus omissions" dichotomy (or the "misfeasance versus nonfeasance" dichotomy). ${ }^{96}$ Some, for example, would argue that, should an individual pass a drowning man and fail to provide assistance, they are not the cause of the man's death. ${ }^{97}$ Similarly, one might argue that unlike the copyright user, who has undertaken some positive action and affirmative conduct (copying), the owners in the OWP case and Field have merely failed to take action that could have prevented the infringement. Some authors in the OWP case potentially noticed the call for information and failed to contact the University in a timely fashion, and likewise, Field simply failed to attach the appropriate meta-tag to his website. Is the copyright user more fairly considered the "cause" of the accident than the owner on the grounds that they have brought about the accident through action rather than inaction? More broadly, is a copyright owner who fails to register her work, attach appropriate notice, and record transfers any less of a cause of a copyright accident?

I find the "omissions argument" unpersuasive as applied to copyright infringement. As a general matter, the omissions doctrine is highly contentious, to the point that several scholars think the distinction cannot be maintained. ${ }^{98}$ But even if we take a less skeptical stance, it is clear that in some cases, our moral intuitions do suggest that individuals can be responsible for outcomes flowing from omissions. If a parent does not feed their child, many of us would say the parent is responsible for causing the child's death. ${ }^{99}$ Tort law is accordingly riddled with exceptions to the omissions doctrine where responsibility is attached to inaction (for example, on the grounds that the defendant assumed responsibility or created a special source of danger). ${ }^{100}$ Much like these other cases in tort law, my moral sense is that the behavior of Field, and the possible behavior of some copyright owners in the OWP case, are "causes" of the accident. Why do I have this sense? I think, in large part,

95. For a similar exploration of this idea in patent law, see Dmitry Karshtedt, Causal Responsibility and Patent Infringement, 70 VAND. L. REV. 565 (2017).

96. See generally RANDOLPH ClARKE, OMISSIONS: AgENCY, METAPHYSICS, AND RESPONSIBILITY (2014).

97. See, e.g., Arthur Ripstein, Three Duties To Rescue: Moral, Civil, and Criminal, 19 L. \& PHIL. 751 (2000) (suggesting a morally intuitive case against the duty to rescue).

98. See, e.g., Robinson v. Chief Constable of W. Yorkshire Police [2018] UKSC 4, [2018] AC 736 (UK) (Lord Reed finding the distinction to be fundamental to the law of negligence; Lord Mance and Lord Hughes expressing doubt on the reality of the distinction).

99. To be sure, it is important to acknowledge that careless copyright owners who, through inaction, cause accidental infringements of their work are not responsible for a result on the same order of magnitude as the death of a child Admittedly, some critics to this argument would say that inaction that results in death of a dependent child who one has a duty to care for is not comparable to inaction that leads to infringement. Nevertheless, this example helps illustrate the principle that most of us would say, at least in some instances, that a person's inaction can make them the responsible party for a result.

100. See Bourhill v. Young [1942] UKHL 5, [1943] AC 92 (appeal taken from Scot.) (example of assumed responsibility); Haynes v. Harwood [1935] 1 KB 146 (UK) (example of special source of danger). 
it is because the copyright owners not only have chosen to produce the works, but have actively sought to enforce copyright in the works for their own economic benefit. The copyright owners seem to have made positive steps to bring about economic gain from copyright, and in doing so, I would argue that they undertake certain moral responsibilities, one of which is to take reasonable care to prevent accidental infringements of their work. Most importantly, the conditions of benefiting from copyright require them to mitigate the chance that others will accidentally infringe upon their rights. Failure to take such other preventative steps, as in Field, is accordingly a cause of the ultimate accident.

At this point, we find ourselves in a familiar position for tort lawyers and philosophers: The conduct of several actors seems to be the cause of the ultimate wrongful outcome. The actions of copyright users and copyright owners in accident cases may potentially satisfy the but-for test. Under such circumstances, how are we to decide who is morally responsible for the outcome? Are they equally responsible? Or is there a way of breaking the deadlock?

In response to this question, many philosophers would give up on the causal inquiry. "Causal minimalists" - who are particularly associated with Legal Realism within legal philosophy ${ }^{101}$-would argue that that both copyright owners and copyright users are causes of the accident because they both pass the but-for test. ${ }^{102}$ Under a causal minimalist framework, if we are to decide that one party bears greater responsibility for the accident, then we must do so on some grounds other than causation principles. In particular, many minimalists would argue that we must do so on more explicitly normative grounds. A simple inquiry into causation cannot attribute responsibility accurately, and thus, under a minimalist view, we must use some alternative moral criterion. ${ }^{103}$

If we go down the causal minimalist route, then the argument that copyright users are not responsible for the Part I infringements becomes even stronger. We have already examined the leading normative criterion for allocating responsibility: culpability. In essence, if we follow the causal minimalist argument, we give up on the possibility of causation providing a reliable indicator of responsibility, and we fall back on the conclusions of the preceding Section A - that strict liability is unfair because it imposes liability on a party who should not be held responsible for the accident because they were not "to blame" for the accident. If we give up on causation as a possible grounds for responsibility, then, in the Part I cases, copyright

101. See, e.g., Leon Green, Are There Dependable Rules of Causation?, 77 U. PA. L. REV. 601 (1929) (discussing causation from a Legal Realist perspective). This view is heavily found in the economically influenced views of tort law. See, e.g., R. H. Coase, The Problem of Social Cost, 3 J.L. \& ECON. 1 (1960) (arguing that causation is "reciprocal").

102. See, e.g., Peter Godfrey-Smith, Causal Pluralism, in THE OXFord HANDBOOK OF CAUSATION 326, 333-34 (Helen Beebee, Christopher Hitchcock \& Peter Menzies eds., 2009).

103. See Perry, supra note 85 . One may also ask: Could a causal minimalist at this point simply decide that both copyright owners and copyright users are equally responsible for the infringement, on the ground that they both are but-for causes? This, however, is unlikely to be the causal minimalist response. As minimalists acknowledge, there are often many hundreds of but-for causes, not all of whom we would consider responsible for the outcome. Thus, it falls to minimalists to develop an alternative way to allocate responsibility as a matter of necessity. 
owners are fairly understood as the responsible party, either because of their active intentions to bring about the accident or because of their carelessness.

Of course, lawyers, for the most part, do not ascribe to the causal minimalist position. In tort law, where there are multiple but-for causes of an accident, lawyers proceed to ask which of these possible causes was the "proximate" cause (or the "legal cause"). ${ }^{104}$ For the most part, this analysis is not considered a normative inquiry, and it is kept distinct from the normative analysis of culpability and blameworthiness, which is found in the breach of duty analysis. Instead, it is an inquiry as to which actor's conduct was, in some sense, "closer" to the ultimate outcome. When considering whose conduct was a proximate cause, courts consult a range of factors, the most important being whether the outcome was a "foreseeable" cause of the conduct (or more specifically whether the particular harm was a foreseeable "type" or "kind" of consequence of the conduct). ${ }^{105}$ Famously, H.L.A. Hart and Tony Honoré argued that this analysis is consistent with how people ordinarily think about causation (as evidenced by the fact that such legal principles are consistent with "ordinary language"), rather than being a normative inquiry in disguise. ${ }^{106}$ Of course, however, the success of the Hart and Honoré's project remains disputed, particularly in North America. ${ }^{107}$

If we discount the causal minimalist argument for the time being, and assume that causation principles can be applied without recourse to normativity, then who is the proximate cause of the copyright accidents in Part I? My intuition is that, in some cases, the copyright user cannot be considered the proximate cause. This is particularly demonstrated by Field. In this case, copyright infringement was not only a "foreseeable" consequence of Field's actions, but it was almost a certainty! It is true that copyright infringement is also a foreseeable consequence of Google's caching (indeed, this is why the meta-tag option to opt out of Google's caching exists). But if we are required to choose between the party who tried to bring about the infringement, and the party who tried to stop it, my intuition is that the former is more proximate to the ultimate outcome. I admit, my intuitions are not quite as clear in the OWP case. Nevertheless, even in this case, I see no reason to label the University of Michigan the proximate cause in preference to the copyright ownersat least in instances where a copyright owner saw the University's call for information but failed to act. Accidental copyright infringement was clearly a foreseeable consequence of the copyright owner's actions: If one fails to respond to a request for information about a work designed to prevent infringement, then copyright infringement is a clearly the proximate cause.

104. Although some notable exceptions are Realist-inspired lawyers who do discuss proximate causation in openly normative terms. See W. Page Keeton, Dan B. Dobbs, Robert E. Keeton \& DAVID G. OWEN, PROSSER AND KEETON ON THE LAW OF TORTS § 42, at 273 (5th ed. 1984) (arguing that proximate cause is better called "responsible cause").

105. See, e.g., Overseas Tankship (U.K.) Ltd. v. Morts Dock \& Eng'g Co. (The Wagon Mound No. 1) [1961] UKPC 2, [1961] AC (PC) 388

106. HART \& HONORÉ, supra note 87, at 254-90.

107. See, e.g., Wright, supra note 87, at 1745-50 (arguing that the Hart and Honoré analysis is better understood as a theory of responsibility rather than causation). 
In summary, if we assume that individuals can be morally responsible for accidents they cause (even when they have not acted culpably), then copyright's strict liability regime still seems unfair. It seems unfair because the acts of both copyright owners and copyright users can potentially cause the copyright infringement. Furthermore, in some cases, copyright owners are plausibly more fairly considered the "cause" of the accident (either because of their culpability, as the minimalists would argue, or because of their proximity, as lawyers might argue). Copyright attaches liability and responsibility regardless of the role that copyright owners may play in bringing about the accident. Nonetheless, there is one potential counterargument to this view worth exploring further. As highlighted at the start of this Section, some argue that causation cannot be a guide to responsibility because of the role luck plays. So, to what extent can one be responsible for copyright accidents that are beyond one's control?

\section{Degree of Control}

One might be tempted to argue that the copyright users from Part I should be considered responsible for the accidents because they had a sufficient degree of "control" over the circumstances leading up to the infringement. ${ }^{108}$ Google, the University of Michigan, and Hearst Magazines all had sufficient capacity to understand copyright law. They all knew (or could reasonably be expected to know) that copying a work that was later found to be protected by copyright would expose them to copyright liability. Nevertheless, they each chose to take a risk and copy the work regardless. There was no pressing need for the copyright users to do this. Indeed, they could have behaved very differently: They could have decided not to copy the works at all, perhaps (in some instances) finding alternatives in the public domain or only copying works for which they first obtained a license. Yet they decided to roll the dice - they put their money on red, but it came up black! —and a lawsuit resulted. Is that not sufficient grounds for holding them responsible for the ultimate outcome?

The initial problem with such arguments is that, to a very significant degree, whether copyright users commit accidental infringement is a matter outside of their control. In Field, although the court found Google's caching was fair use, whether or not Google cached Field's website and works in the first place - in other words, whether or not the potential for copyright infringement existed - depended very significantly on whether Field attached the relevant meta-tag. ${ }^{109}$ Likewise, whether the University of Michigan committed copyright infringement depended significantly on the actions of the relevant copyright owners. ${ }^{110}$ Had the copyright owners responded to the University's call for information, the University most likely would not have committed the infringement. To put the same point another way, the copyright owners in these cases also exercise significant control over the probability

108. See, e.g., JOHN MARTIN FISHER \& MARK RAVIZZA, RESPONSIBILITY AND CONTROL: A THEORY OF MORAL RESPONSIBILITY 14-16 (1998).

109. Field v. Google Inc., 412 F. Supp. 2d 1106 (D. Nev. 2006).

110. Authors Guild, Inc. v. HathiTrust, 755 F.3d 87 (2d Cir. 2014). 
that a defendant will accidentally infringe their copyright. Yet, despite the copyright owner's control of the situation, the copyright user is held solely responsible when a court finds that infringement has occurred.

Nevertheless, perhaps the need for a copyright user to have control over the situation is exaggerated. Some would argue that, under certain conditions, we may be responsible for outcomes that, due to the influence of luck, are outside of our control. Tony Honoré famously made this claim as part of his theory of "outcome responsibility" 111 (following the introduction of the moral luck problem into the literature by Thomas Nagel and Bernard Williams ${ }^{112}$ ). Consider, for example, a driver who has missed a turn in the road and is considering how to rectify the mistake. The driver has two options: either keep going to the next roundabout, or alternatively, make a U-turn in the road. ${ }^{113}$ Honore argues that if the driver makes a U-turn, then she will be responsible for the outcome, regardless of whether that outcome is good or bad. More often than not, the outcome will be good: The driver will complete the U-turn with no bad consequences and get to her destination more quickly. In these cases, the driver benefits from her good fortune. Every so often, however, the driver will experience bad luck: She will not see a driver coming in the other direction, and the maneuver will result in an accident; our driver did not want to cause this accident, but in this instance she simply did not spot the oncoming traffic. Honoré claims that because we enjoy the benefit of good luck, we must also bear the responsibility of bad luck; we must, in other words, take "the rough with the smooth." 114 Likewise, our defendants in Part I have chosen to take a risk. More often than not, their decisions to copy will be to their benefit (Google clearly benefits from their activity more often than not). Should they not also accept responsibility in these minority of cases where, to an extent, they infringed copyright as a result of bad luck?

The outcome-responsibility argument, however, faces the same type of problems that we covered in Section B on causation. Namely, both the copyright owner and the copyright user have caused the outcome, in a sense, and thus both bear some of the responsibility. A major objection to Honoré's U-turn example is that while the driver has made a calculated bet in taking the U-turn, the same can be said of the oncoming motorist. The motorist has likewise made a series of decisions that have led to the accident, for example, to take the car that day rather than public transit, and to take this particular route rather than an alternative slower route. Without introducing some additional normative standard, the concept of outcomeresponsibility leads to an indeterminate allocation of responsibility. ${ }^{115}$ The same is true in the copyright cases. The copyright owners in the Part I cases equally made decisions leading to the accident. The copyright owners in the OWP case did not

111. Honoré, supra note 81.

112. ThOMAS NAGEL, Moral Luck, in MORTAL Questions 24, 24-38 (1979); BerNARD WiLliamS, Moral Luck, in MORAL LUCK: PHILOSOPHICAL PAPERS 1973-1980, at 20-39 (1981).

113. Honoré, supra note 81, at 539.

114. Honoré's original essay did not include this particular phrase, but it was subsequently adopted in TONY HONORÉ, RESPONSIBILITY AND FAULT 9 (1999).

115. See Perry, supra note 85 , at $488-96$. 
ensure that their claim was appropriately registered with the Copyright Office and did not respond to the University's opt-out scheme, and thus were equally as 'outcome-responsible' as the University for the infringement.

\section{COUNTER-ARGUMENTS}

The previous Part posited that strict liability seems unfair to many because, in some cases, it results in copyright users being held liable for accidents for which they are not morally responsible. This Part continues the analysis by considering a range of counter-arguments. It considers and rebuts the following claims: (a) that strict liability is an essential feature of property rights; (b) that whatever unfairness exists is easily resolved by a more lenient approach to copyright remedies; and (c) that fairness is not a relevant value in copyright law.

\section{A. Copyright as a Property Right}

When a lawyer questions the strict liability standard in copyright (often at a workshop, seminar, or symposia), almost inevitably someone will ask a question to the effect of: "But isn't copyright a property right?" 116 Putting aside the fact that in many jurisdictions copyright involves rights of personhood too (such as moral rights), this question is interesting, but ambiguous. On one level, saying "Isn't copyright a property right?" is a non sequitur; certainly copyright's economic rights are understood as property rights, but this says nothing about what the liability structure ought to be. Nevertheless, the argument cannot be simply brushed aside with a simple reaffirmation of the positivist distinction between "is" and "ought." Underneath the question lurk two more interesting arguments, which often go unarticulated. The first argument posits that property has an "essence," that is, a core conceptual content without which something cannot rightly be considered "property," 117 and that strict liability is a necessary part of that essence. In this case, would changing the strict liability regime in copyright involve an acknowledgement that copyright's economic rights are not property rights? That may be a desirable outcome, but would surely require much more deliberation and justification than I have offered thus far in this Article. By contrast, the second version of the property argument does not rely on any "essential" features of property. Instead, it highlights that many of the arguments made in this Article could equally apply to cases of real property violations. For example, the defendant who, without awareness of the legal entitlements, trespasses on a property owner's land equally incurs strict liability, although they are equally blameless. The question is then: Should real property's strict liability rule also be abandoned? Or alternatively, is there a meaningful

116. And, to an extent, it is found in the literature. See, e.g., Ciolino \& Donelon, supra note 63, at 371-76 (considering and rebutting the argument).

117. For example, see the view that property is essentially a "right to things" in J. E. PENNER, THE IdeA OF Property In LAw 2 (1997). See also Henry E. Smith, Property as the Law of Things, 125 Harv. L. REV. 1691 (2012). 
difference between the defendant in a tangible property case and the intangible property case?

I reject the argument that strict liability is an essential feature of property rights. Property may or may not have an essence; that is beyond the scope of this Article. But the secondary claim that if property does have an essence then strict liability is part thereof, I find unpersuasive. In large part, I come to this conclusion because at least some property violations are remedied via negligence liability rules. For example, if I crash into your car on the public highway, then I will only be liable for the damage if I behaved negligently; I will not be held responsible for the outcome if that was merely an unfortunate product of fate. ${ }^{118}$ This example suggests strongly that if property has any essential features, negligence liability is, under some conditions, compatible with those features. ${ }^{119}$ Of course, at this point, some may object. These objectors might say that this example involves damage of property rather than a trespass upon the property, and the distinction is somehow meaningful. Yet, I doubt this distinction between damage and trespass is significant. If anything, damaging someone else's property is a far greater offense, and far more incompatible with the essence of property, than a mere trespass. Surely if any property rights required protection via strict liability, it would be cases of damage? Taking this argument further, perhaps some will simply state that cases of damage to property ought to be remedied via strict liability, not negligence liability. I'd argue that the burden must fall on the reformer to make the case for change. There is no great moral outrage (to my knowledge) that liability is imposed for accidental property damage only when the defendant behaved carelessly. At root, I think this is because, in cases of accidental infringement or violation of property rights, imposing liability only when the defendant behaved carelessly is compatible with the idea of property. ${ }^{120}$ Or, to put it another way, I think we have, to an extent, already accepted that in some cases, strict liability is not required to remedy interference with property rights.

Nevertheless, by arguing that copyright ought not impose liability strictly in cases of accidents, I do not claim that liability for other types of property violations necessarily ought to follow suit. In particular, I am not making the claim that an accidental trespasser on real property ought to be held liable only if she behaved negligently. Nor do I rule out that such a reform may be beneficial. ${ }^{121}$ Nevertheless, some of the significant differences between real property and intangible property render strict liability plausibly appropriate in the former, but nevertheless inappropriate in the latter. In particular, the issue of "control" is once again significant. Avoiding accidental infringement of real property rights is significantly more within a defendant's control than avoiding accidental infringement of

118. See generally RestatemEnt (SECOND) OF TORTS $\S \S 497-99$ (AM. L. INST. 1965); DAN B. DobBs, Paul T. HAYden \& Ellen M. Bublick, The LaW OF TORTS $\S \S 120-25$ (2d ed. 2020).

119. See Perry, supra note 85, at 151-52 (responding to Epstein, supra note 83; arguing that despite Epstein's conceptual claim, there is no reason property conceptually requires strict liability rather than fault liability protection).

120. See generally Guido CALABRESI, THE COSTS OF ACCIDENTS (1970).

121. See Stewart E. Sterk, Strict Liability and Negligence in Property Theory, 160 U. PA. L. REV. 2129, 2132-33 (2012) (arguing that negligence liability rules should be used more often in property law). 
copyright. If I wish to avoid becoming a trespasser, I must pay attention to a small number of property rights that are in my immediate vicinity. Furthermore, the subject matter of that property - the land - has reasonably clear boundaries, marked by various physical boundaries, and the ownership status is relatively easy to ascertain. ${ }^{122}$ Should a defendant fail in this relatively simple duty, it does not strike me as grossly unfair to hold her strictly liable. By contrast, avoiding copyright accidents is a highly onerous, and increasingly impossible, task. There is no geographic limitation on copyright accidents: While I can only trespass on the land of those immediately around me, I can trespass on the copyrights of people in every corner of the world. Avoiding copyright accidents thus requires me to take into account a much broader set of possible right holders. Furthermore, those right holders are often not easily identifiable, and the boundaries of their rights are nebulously defined due to the intangible nature of creative works. ${ }^{123}$ The result is that a future defendant in a case similar to Authors Guild v. HathiTrust can take very significant levels of precaution, just as the University of Michigan prepared to do, and nevertheless still have the potential to become an accidental infringer. By expecting copyright defendants to avoid all copyright accidents, we hold them to an impossible standard. The fact that avoiding accidental trespass upon real property is reasonably within the scope of the defendant's control, in a way that it largely is not with respect to copyright, suggests that a defendant is morally responsible for the former accident in a way that they are not for the latter. ${ }^{124}$

\section{B. Changes To the Remedies Available for Infringement}

A second potential counter-argument is that, even if the strict liability rule is unfair, this unfairness can be resolved by changes to the monetary remedies available in cases of accidental infringement. ${ }^{125}$ This solution, to a certain extent, is already adopted in many jurisdictions. ${ }^{126}$ In the United States, for example, if the copyright owner elects for statutory damages (as opposed to actual damages), the court can reduce the damage award to "a sum of not less than $\$ 200$ " in cases where the infringer "was not aware and had no reason to believe that his or her acts constituted an infringement of copyright." 127 This section was added to U.S. copyright law as the strict liability standard solidified, to provide some protection to the accidental infringer. Reese's history demonstrates that, as copyright law removed elements of

122. On the comparison between tangible and intangible property in this regard, see Dorfman \& Jacob, supra note 63 , at $72-80$.

123. Id. at $80-96$.

124. This observation has been made for many years in relation to strict liability in copyright. See Innocent Participants in Copyright Infringement, supra note 49, at 401 ("[Copyright] is a prohibition of conduct remote from the persons or tangibles of the party having the right. It may be infringed by persons thousands of miles away from the owner. In order, therefore, not to make the prohibitions of the statute beyond measure, protection to the public is afforded by a strict requirement that notice of copyright, in the manner provided by the statute, be affixed to each copy of the work published or offered for sale in the United States.").

125. See Bell \& Parchomovsky, supra note 57, at 682.

126. See, e.g., Copyright, Designs and Patents Act 1988, c.48 § 97 (U.K.).

127. 17 U.S.C. $\$ 504$. 
fault from its liability standard, and as copyright formalities (designed to prevent accidental infringement) became less mandatory, the drafters of the Copyright Act of 1976 perceived a need to provide some measure of protection to those who infringed copyright without awareness. ${ }^{128}$ The reduction in statutory damages was deemed to be "sufficient to protect against unwarranted liability in cases of occasional or isolated innocent infringement." ${ }^{129}$ Of course, it does not protect such an infringer from injunctive relief, awards of actual damages, or disgorgement of profits.

Ultimately, I disagree with the belief that reduction in damages is sufficient to resolve the unfairness of the strict liability standard. By imposing liability on a defendant, the court makes a public pronouncement that the defendant is responsible for some wrongful outcome. ${ }^{130}$ As the defendant is responsible, she accordingly has a duty to repair the situation. By reducing the damages available in cases of accidental infringement, courts essentially find that the copyright user is responsible for the copyright infringement, but, due to mitigating factors, the level of corrective measures required is smaller than it otherwise would be. They may need to pay a smaller amount of damages, but they are still the recipient of state censure, and their name would still go down in the law reports as a copyright infringer. This strikes me as unfair to the defendants we discussed in Part I. I would argue that most people have an intuitive sense that the copyright users in these cases are not responsible for the outcome. If our intuitions are right, and they bear little moral responsibility for the outcome, then what is the basis for holding them liable at all? This Article argued in the previous Part that if the copyright users are not morally responsible for the copyright infringement, then courts should absolve them of liability, not hold them liable while simply reducing the damage award. Although not discussed in Part I, the "subconscious copying" cases, wherein a musician unknowingly reproduces parts of a popular song, are a great example where liability, even with reduced damages, seems particularly out of step with our notions of responsibility. ${ }^{131}$

\section{CONSEQUENTIALISM AND COPYRIGHT INFRINGEMENT}

A final possible counter-argument is that my concern for fairness in this Article is simply misplaced. Copyright law, particularly in common law jurisdictions, is justified on consequentialist grounds. As the U.S. Constitution says, Congress has the power to enact IP rights in order "To promote the Progress of Science and useful

128. Reese, supra note 13 , at $179-82$.

129. H.R. REP. NO. 94-1476, ch. 5, at 163 (1976), cited in Reese, supra note 13, at 182.

130. Many scholars have provided "responsibility-based" accounts of tort law. See generally Stephen R. Perry, Responsibility for Outcomes, Risk, and the Law of Torts, in PHILOSOPHY AND THE LAW OF TORTS 72 (Gerald J. Postema ed., 2001). Perhaps the leading such responsibility-based account today is found in Civil Recourse theory. See GoldBERG \& ZIPURSKY, supra note 73, at 187-204; see also John C.P. Goldberg \& Benjamin C. Zipursky, Tort Law and Responsibility, in PHILOSOPHICAL Foundations OF THE LAW OF TORTS 17 (John Oberdiek ed., 2014).

131. See, e.g., Bright Tunes Music Corp. v. Harrisongs Music, Ltd. 420 F. Supp. 177 (S.D.N.Y. 1976). 
Arts." ${ }^{132}$ A consequentialist would argue that we judge copyright by whether the law leads to good or bad outcomes, not whether it reflects our sense of fairness. In particular, many consequentialists would argue that copyright is justified on the economic-utilitarian ground that, in the absence of legal protection, authors would underproduce creative works, and the resulting market failure would lead to lower social welfare (or preference satisfaction, or perhaps even wealth) in the future. ${ }^{133}$ If this is acknowledged as the primary justification for copyright, then whether copyright liability should be strict or not is a question that must be judged according to the same social welfare maximization goal. ${ }^{134}$ This argument can be rephrased in less utilitarian terms: In order to be "coherent," the liability structure should match the underlying normative values of the law. ${ }^{135}$ Elsewhere, Bracha and I have argued that strict liability should give way to negligence liability precisely for consequentialist (particularly economic) reasons. ${ }^{136}$ Nevertheless, putting this aside for the moment, does fairness have a place to play in informing the liability standard in copyright?

I think fairness is an appropriate value to consider when judging copyright's liability standard. For the moment, let us assume that the primary justification for copyright is consequentialist. We have a copyright system because we think it will lead to more happiness, a more attractive culture, or even simply a wealthier society. It does not follow, however, that other human values, such as our sense of fairness, automatically fall away. In particular, I believe that other human values constrain and influence what copyright lawmakers can do in pursuit of good social consequences. One potential illustration of this comes in the form of statutory damages. In the United States, a copyright owner can elect to obtain statutorily defined damages rather than actual damages. If the copyright owner makes such an election and the infringement is found to be willful, the court can order the defendant to pay damages up to $\$ 150,000$ per work, even if the actual damage done is quite minimal. ${ }^{137}$ It is plausible that there is sound economic sense to this damage provision. Copyright infringement is hard to detect, and in order to provide an adequate deterrence, the level of damages must be punitively high when willful infringement is found. ${ }^{138}$ Such punitive damages may be necessary therefore to ensure the copyright system works as a whole. Nevertheless, even if - a big "if"such heightened damages do lead to good consequences as a whole, it can lead to

132. U.S. CONST. art $8, \S 8, \mathrm{cl} .8$.

133. See, e.g., Stephen Breyer, The Uneasy Case for Copyright: A Study of Copyright in Books, Photocopies, and Computer Programs, 84 HARV. L. REV. 281, 293-94 (1970).

134. To do otherwise may, to some, seem irrational. See, e.g., Mark A. Lemley, Faith-Based Intellectual Property, 62 UCLA L. REV. 1328, 1340-42 (2015).

135. See, for example, Dworkin's view that law should be interpreted creatively, in light of the best normative justifications for that area of law. RONALD DWORKIN, LAW'S EMPIRE (1986).

136. Bracha \& Goold, supra note 14, at 1029-56.

137. 17 U.S.C. $\$ 504$.

138. See generally Gary S. Becker, Crime and Punishment: An Economic Approach, 76 J. PoL. ECON. 169 (1968). But see Oren Bracha \& Talha Syed, The Wrongs of Copyright's Statutory Damages, 98 TEX. L. REV. 1219, 1238-40 (2020) (discussing the optimal deterrence justification for copyright's statutory damages). 
individual cases where the damages seem grossly excessive in proportion to the harm committed, and are thus morally unfair to the individual who is forced to pay them. In such cases, the individual is forced to pay a supra-compensatory remedy. They are being required to pay money far in excess of that which is needed to correct the wrongful outcome for which they are responsible. ${ }^{139}$ In such a case, I believe fairness ought to constrain copyright law, and it generally provides a reason for rejecting punitive statutory damages. While the underlying justification may be consequentialist, in a case like this, fairness may need to restrain what we do in the name of good consequences. I think the same is true when it comes to the liability standard. Given this, it's clear that copyright's strict liability standard is in need of reform. But what form should this take? As explained in Part IV, a negligence liability rule is one such reform that would lead to good consequences. But even if it did not, fairness alone should make us reconsider the strict liability rule.

\section{REFORMING COPYRIGHT'S STRICT LIABILITY STANDARD: REPLACING STRICT LIABILITY WITH NEGLIGENCE}

Adopting a negligence liability rule in copyright would seem to be appropriate from our perspective of fairness. Under such a rule, a copyright user should not be held liable for any infringements for which they had adopted all reasonable care to avoid infringement. In all of the cases identified in Part I, the defendants should have been absolved of liability on the ground that they had adopted the care that a reasonable person would have taken in order to avoid the accidental infringements.

In one respect, this proposal is less radical than it could be. One plausible alternative is to argue that copyright users should not be held liable when they do not "intend" copyright infringement. ${ }^{140}$ Indeed, this proposal would seem to be consistent with some of the philosophical literature we have come across in this Article. ${ }^{141}$ But such a big reform would push allocation of legal responsibility too far in the other direction. Hypothetically, imagine an alternative situation where the University of Michigan found the old works in their library and decided to press ahead with releasing digitized copies of these works without adopting any measures designed to avoid infringement. If the copyright holders later came forward and sued, the University would be able to claim that, because they were unaware of any copyright or copyright holders, they had not intended the infringement and thus are not liable. This outcome does not strike me as significantly fairer than our current situation. In a hypothetical case like this, where the defendant has behaved carelessly, I believe the copyright holders are justified in seeking damages. This would be frustrated under a rule that only intentional infringements can result in a remedy.

139. See Patrick R. Goold, Corrective Justice and Copyright Infringement, 16 VAND. J. ENT. \& TECH. L. 251, 285-87 (2014).

140. Some of the literature has discussed this as a possibility. See Lipton, supra note 63, at 804 . Some have also sought for a limited role of intent in the infringement and/or fair use analyses. See Eva E. Subotnik, Intent in Fair Use, 18 LEWIS \& CLARK L. REV. 935, 976, 978-80 (2014).

141. See WALLACE, supra note 68 , at 51-53. 
But in another respect, the proposal is more generous to the copyright users than other conceivable reforms. For example, rather than adopt a simple negligence rule, an alternative solution would be to keep the strict liability rule but adopt a contributory negligence defense. ${ }^{142}$ Under such a rule, the defendant would be liable for the infringement unless she could show that the copyright owner behaved negligently. Such a solution would indeed resolve the sense of unfairness present in future cases with facts similar to the OWP case and Field, where - unlike the OWP case and Field - the court finds the defendants liable for copyright infringement despite the accidental nature of the infringement. In such cases, it is likely that the defendants will be able to demonstrate that the copyright owners were at fault for the accident, and thus the defendants should avoid liability. Nevertheless, this would not go far enough to remedy the unfairness caused in the copying by derivation cases. Let us consider De Acosta again. ${ }^{143}$ Let us assume that the copyright owner took all reasonable steps to avoid the copyright infringement (she appropriately registered her work, attached notice, etc.), and on this ground could not be said to be contributorily negligent. Brown then copied the work, and gave the copied work to Hearst Magazines for publication (being sure to remove any information which would allow Hearst to learn the true source of the material, such as any copyright notice). Let us assume that Hearst adopted due care and tried to confirm that by reprinting Brown's manuscript they were not committing copyright infringement by derivation (copying a copy). But even when exercising due care, Hearst is at a substantial disadvantage. They could of course ask Brown whether the manuscript was copied, but it is likely Brown would not be truthful. Furthermore, even if Hearst suspects Brown is being untruthful, there is very little they can do to discover that Brown's work contains copyrighted elements from third-party works. Hearst had no knowledge of what source material Brown had copied, and accordingly, an attempt to discover whether that source material was protected by copyright was not feasible. In cases like these, where the copyright owner has not behaved negligently, a diligent copyright user may ultimately infringe copyright. Under a strict liability regime that includes a contributory negligence defense, a number of copyright users, like Hearst in this scenario, will be held liable for copyright infringements for which they are not truly responsible.

Fortunately, in the United States and many other jurisdictions, copyright law could be changed to a negligence liability rule in a relatively straightforward manner. Bracha and I have previously demonstrated, in detail, how the fair use analysis could be modified with somewhat minor tweaks in order to ensure that only defendants who behave carelessly will be held liable for accidental infringement of copyright. ${ }^{144}$ In non-accident cases, no modifications to the doctrine are required. Accident cases involving uses that are clearly fair even in non-accident circumstances likewise require no modification to the analysis. However, when a court determines that the

142. For such a proposal in patent law, see generally Tun-Jen Chiang, The Reciprocity of Search, 66 VAND. L. REV. 1 (2013). See also Bracha \& Goold, supra note 14, at 1048 (considering contributory negligence in copyright).

143. De Acosta v. Brown, 146 F.2d 408, 411 (2d Cir. 1944).

144. Bracha \& Goold, supra note 14 , at 1072-74. 
defendant's action substantially involved only a risk of infringement and that the action would not be clearly fair if the case had been a non-accident case, the fair use doctrine must be modified to evaluate whether the defendant's level of care was less than reasonable. If the defendant failed to take a reasonable precautionary measure, then the use will not be fair. Alternatively, if she did take these precautions - that is, if she was not negligent - then the use will be fair. ${ }^{145}$ As Congress expects courts to assess the "purpose and character" of the defendant's use, the negligence analysis could formally fit under this fair use factor. ${ }^{146}$ However, for analytic clarity, it is preferable if courts conceive of the extra negligence inquiry as a separate and additional factor as they are authorized to do. ${ }^{147}$ The result of this is that the burden would fall on the copyright user to prove they behaved non-negligently. But this is an acceptable drawback for the convenience of incorporating the negligence analysis within the existing fair use doctrine. Furthermore, because this change does not radically disrupt the fair use inquiry, other countries that have a fair use doctrine (such as Israel), are equally able to incorporate a negligence standard into their fair use laws. ${ }^{148}$

We have previously demonstrated how such a modification would be legally and politically feasible. ${ }^{149}$ In particular, courts have, in recent times, shown a willingness to adapt the contours of the fair use inquiry to suit various socioeconomic realities and normative concerns. For example, the transformative use criterion only became incorporated into fair use law in 1994 following the Supreme Court's decision in Campbell v. Acuff-Rose Music, Inc. ${ }^{150}$ Subsequently, this has factor has come to dwarf the other fair use factors in several recent court opinions analyzing fair use. ${ }^{151}$ This modification was entirely in keeping with Congress's desire to avoid a rigid, inflexible test for fair use and instead allow courts to adapt the doctrine to changing conditions. Perhaps even more significantly, such a modification would serve the underlying purpose of the doctrine. The doctrine is sometimes called an "equitable rule of reason" and, even more tellingly, the doctrine is the "fair" use doctrine. ${ }^{152}$ The rule has always existed to remedy unnecessary harshness within copyright. By introducing a negligence standard into this doctrine, the modified fair use analysis will better live up to the role of ensuring fairness within copyright law.

Of course, outside the United States and other fair use jurisdictions, adopting a negligence liability rule presents unique challenges. Without a fair use doctrine, the

145. $I d$.

146. 17 U.S.C. $\$ 107$.

147. 17 U.S.C. $§ 107$ (“[T] he factors to be considered shall include ...”); see also Field v. Google Inc., 412 F. Supp. 2d 1106, 1122 (D. Nev. 2006) ("The Copyright Act authorizes courts to consider other factors than the four non-exclusive factors discussed above. See 17 U.S.C. $\S 107$ (noting court is to consider factors including four specifically listed).").

148. Copyright Act 2007, 5768-2007, 2007 LSI 34 (Isr.).

149. Bracha \& Goold, supra note 14, at 1072-74.

150. 510 U.S. 569 (1994).

151. Neil Weinstock Netanel, Making Sense of Fair Use, 15 LEWIS \& CLARK L. REV. 715, 715 (2011) (finding "the transformative use paradigm has come overwhelmingly to dominate fair use doctrine" in cases decided after 2005).

152. See Sony Corp. of Am. v. Universal City Studios, Inc., 464 U.S. 417, 448 n.31 (1984). 
most logical way forward would be to introduce a negligence standard into the prima facie copyright infringement analysis. Currently most jurisdictions require that the defendant "copy" a "substantial part" (or language to that effect) of the original work. ${ }^{153}$ If such copying is found, the defendant will be liable unless she can show how her use fell within the bounds of a relevant exception. In these jurisdictions, the most likely way to introduce a negligence principle would be introduce a third requirement: carelessness. A defendant would be liable if she copied a substantial part of the work and had not adopted all reasonable care in the circumstances. Note that under such a regime, the burden of proof would not need to be assigned to the plaintiff. It is entirely consistent with the argument of this Article to require a copyright owner to prove the defendant copied a substantial part of his work, at which point the defendant will be presumed responsible for the infringement unless she can rebut that presumption by showing she adopted all reasonable care. Adopting this solution is less preferable than making modifications to the fair use analysis. Unlike the fair use analysis, the copyright infringement analysis in most jurisdictions has been relatively stable for many years, and modifications would require arguably more upheavals. Nevertheless, in countries without a fair use analysis, it would seem not only the most likely way forward; it is also within the jurisdiction of the courts to implement. In the United Kingdom, as with many other jurisdictions, the relevant copyright legislation is silent on the liability standard and can be modified by courts without legislative intervention. A recent example from the European Union is in the case GS Media BV v. Sanoma Media Netherlands BV, in which the CJEU found that a defendant could not be held liable for "communication to the public" of copyrighted works when posting hyperlinks to such content online unless the defendant could have reasonably known about the unlawful nature of the online content. ${ }^{154}$ This would be a small step in the right direction.

\section{CONCLUSION}

Copyright's strict liability rule was created by judges in an era where mandatory formalities greatly limited the possibility of accidental infringement. In the twentieth century, those safeguards have been whittled away and, as a result, the accidents problem has grown substantially. Now more than ever, it is easy for copyright users to accidentally infringe copyright. In these cases, the law holds users strictly liable for their infringement. But, as this Article has explored, strict liability has long felt harsh and unfair. This Article has attempted to explore these intuitions surrounding strict liability. I argue that the reason strict liability appears harsh is because it results in copyright users being held liable for infringements for which they are not morally responsible. The current liability structure seems to hold users liable when they are not really "to blame" for the accident, when they are not "the cause" of the accident, and when the accident was largely outside their scope of "control." Furthermore, in some cases, the current rules hold users liable when other parties, particularly

153. See, e.g., Designers Guild Ltd. v. Russell Williams (Textiles) Ltd. (t/a Washington DC), [2001] E.C.D.R. 10.

154. C-160/15, GS Media BV v. Sanoma Media Neth. BV, ECLI:EU:C:2016:221 (April 7, 2016). 
copyright owners or intermediate users, seem to bear greater responsibility for the wrong. If these intuitions are shared by others, then the unfairness could be remedied within the United States (and similar jurisdictions) by adopting a negligence factor within the fair use analysis. The fair use doctrine could, in this way, become even fairer. 